\title{
Cardinal Stepinac as an Important Element in the Shaping of Croatia's National Brand
}

Preliminary communication _ DOI 10.22522/cmr20200156_ received on 28 October 2019

UDK: $005.6: 2-7(497.5)$

\section{Davor Trbušić, PhD Candidate}

Faculty of Croatian Studies, University of Zagreb, Zagreb, Croatia.

E-mail: dtrbusic@hrstud.hr (corresponding author)

\section{Stipan Rimac, PhD Candidate}

Fabular branding agency, Zagreb, Croatia

E-mail: stipan.rimac@gmail.com

\begin{abstract}
Croatia's national identity is inseparable from the Christian and Catholic identity, which has developed along with the Croatian people throughout its fourteen centuries of history. Many great spiritual individuals have indebted Croatia with their work and life, thus remaining remembered in the collective memory of the Croatian people. One of them is certainly Alojzije Stepinac, Archbishop of Zagreb and Cardinal. Since the assessment of Cardinal Stepinac's character and work - even fifty-nine years after his death - has not ceased to stir significant interest in the Croatian public space, the following problem question arises: Is Cardinal Stepinac perceived as a positive or a negative element of Croatia's national brand? Therefore, this paper, which focuses on the study of the student population's perceptions of Cardinal Stepinac, analyzes the image of this church dignitary among respondents. Furthermore, the paper addresses the question of whether the Church in Croatia, as a brand should make greater efforts in the future to communicate its sub-brands, which are woven into the development of Croatia's national identity. Key research findings have shown that most respondents perceive Cardinal Stepinac as a positive historical figure that contributes to the positive perception of Croatia's national brand. In addition, research respondents mostly inform themselves about Cardinal Stepinac through traditional media, while on the other hand, efforts of the Church in Croatia to publicly communicate their brands were considered insufficient.
\end{abstract}

Keywords: branding, Catholic Church, brand architecture of the Church, Church sub-brands, Church communication, Alojzije Stepinac 


\section{Kardinal Stepinac kao element u oblikovanju imidža nacionalnog brenda Hrvatske}

Prethodno priopćenje_DOI 10.22522/cmr20200156_primljeno 28. listopada 2019.

UDK: $005.6: 2-7(497.5)$

\section{Davor Trbušić, doktorand}

Fakultet hrvatskih studija Sveučilišta u Zagrebu, Zagreb, Hrvatska.

E-pošta: dtrbusic@hrstud.hr

\section{Stipan Rimac, doktorand}

Fabular branding agency, Zagreb, Hrvatska.

E-pošta: stipan.rimac@gmail.com

\section{Sažetak}

Nacionalni identitet Hrvatske neodvojiv je od kršćanskog i katoličkog identiteta, koji je kroz 14-stoljetnu povijest srastao s hrvatskim narodom. Mnogi su velikani duha svojim radom i životom zadužili Hrvatsku te tako ostali upamćeni u kolektivnoj memoriji hrvatskoga naroda. Jedan od njih je zasigurno i Alojzije Stepinac, zagrebački nadbiskup i kardinal. Budući da ni pedeset devet godina nakon njegove smrti valorizacija lika i djela kardinala Stepinca ne prestaje izazivati velik interes u hrvatskom javnom prostoru, nameće se sljedeće problemsko pitanje: Je li kardinal Stepinac percipiran kao pozitivan ili negativan element nacionalnog brenda Hrvatske? Stoga ovaj rad, u čijem je središtu istraživanje o predodžbama studentske populacije o kardinalu Stepincu, analizira kakav imidž među ispitanicima uživa taj crkveni velikodostojnik. Rad se bavi i pitanjem treba li Crkva u Hrvatskoj kao stanoviti brend u budućnosti uložiti veće napore pri komuniciranju svojih podbrendova, koji su utkani u izgradnju hrvatskog nacionalnog identiteta. Ključni rezultati istraživanja pokazali su kako većina ispitanika kardinala Stepinca percipira kao pozitivnu povijesnu ličnost koja doprinosi pozitivnoj percepciji nacionalnog brenda Hrvatske. Također, sudionici istraživanja se o kardinalu Stepincu najviše informiraju putem tradicionalnih medija, dok su s druge strane napore Crkve u Hrvatskoj pri komuniciranju svojih brendova u javnosti ocijenili nedovoljnima.

Ključne riječi: brendiranje, Katolička crkva, brend arhitektura Crkve, crkveni podbrendovi, crkvena komunikacija, Alojzije Stepinac 


\section{Uvod}

Brending je u svojoj definiciji marketinški alat čiji je cilj stvaranje diferencijacije $u$ usporedbi s drugim proizvodima tako da ističe svoju neuobičajenost, ili čak jedinstvenu kvalitetu (Olins, 2008). Time se u odnosu na konkurenta stvara psihološka prednost kod potrošača, koji se zbog toga snažnije i lakše priklanjaju nekom proizvodu ili proizvođaču (Kotler, 2000). Takav, na profit orijentiran i dijelom manipulativni koncept brendinga, primjenjiv je na većinu društvenih organizacija, no postavlja se pitanje vrijede li njegove univerzalne zakonitosti i kada je riječ o organizaciji koja je, uz to što je ljudske, i transcendentne naravi? Površnom aplikacijom zakona brendinga (koji će detaljnije biti objašnjen u poglavlju br. 2) u Katoličkoj crkvi, ali i religiji općenito, stvara se rizik da se vjeru pretvori u proizvod, a vjernike u puke potrošače koji će birati vjeroispovijest po kriterijima tržišta.

Znanstveni i stručni okvir koji se bavi istraživanjem implementacije metoda brendinga u kontekstu kršćanskih religija u Hrvatskoj još nije dovoljno razvijen, dok suvremene primjene marketinga $\mathrm{u}$ vjerskim zajednicama, osobito u protestantskim i evanđeoskim, mogu se smatrati 80-te godine 20. stoljeća (Balog, 2012). Osim toga, ovaj rad problematizira srž brenda Katoličke crkve utemeljen u njezinu poslanju te ukazuje na činjenicu da svaka mjesna Crkva, zahvaljujući svojoj različitosti, ima svoje podbrendove, koji u konačnici tvore cjeloviti imidž nacionalnog brenda i brenda Katoličke crkve. Stoga je u središtu ovog rada istraživanje o Alojziju Stepincu, zagrebačkom nadbiskupu i kardinalu kao elementu u oblikovanju imidža brenda države Hrvatske. I dok se ostala istraživanja bave znamenitim ličnostima u povijesti Hrvatske općenito, ovo je istraživanje posebno po tome što prvi put ispituje konkretnu predodžbu, asocijacije i imidž konkretne crkvene ličnosti, čije djelovanje i danas izaziva velik interes $u$ hrvatskoj javnosti.

\section{Pregled ključnih pojmova u brendingu:
definicije, ciljevi i elementi brenda.}

Kako bismo što bolje razumjeli problematiku brendinga u kontekstu organizacije kao što je Katolička crkva, vrlo je važno krenuti od definiranja ključnih pojmova: što je brend, koje su njegove značajke, na koji se način uspješno gradi brend te koji su njegovi ciljevi. Isto tako, $u$ tu je svrhu potrebno i definirati zakonitosti brenda poput pozicioniranja brenda, njegove srži, osobnosti i imidža. 
Prema Američkoj marketinškoj asocijaciji (AMA) brend se definira kao dizajn, ime, termin, znak, simbol ili kombinacija istih elemenata koji su usmjereni na identifikaciju proizvoda ili usluga nekog proizvođača ili grupe proizvođača te njihovo razlikovanje od proizvoda ili usluga konkurencije. Brendovi su, kako ističe Olins, „jasan i jedinstven odraz našega vremena $u$ kojem je razuman izbor postao gotovo nemoguć pa oni posljedično predstavljaju jasnoću, novu sigurnost, dosljednost, status i članstvo - sve što pomaže ljudima da se odrede" (2008, str. 28). U konačnici, brend je odnos za koji je potrebna „ljubav i strast, osjećaj pripadnosti i potvrđivanja, međuzavisnost, predanost, intimnost, kvalitetno partnerstvo te nostalgičnost i inovativnost” (De Chernatony, McDonald, 2005, str. 144).

Upravo su ti elementi diferencijacije ključna značajka koncepta brendinga koja omogućava razlikovnost proizvoda u svijesti potrošača (Kotler, Gertner, 2004). Svaki dobro izgrađen brend služi kao oznaka kvalitete i prepoznatljivosti koji kupcima olakšava odluku o kupnji, a to čini kreiranjem jedinstvenog seta funkcionalnih i emotivnih elemenata (Dibb i sur., 1995). To su jedinstveni i za sâm brend upečatljivi elementi poput upotrebljivosti, cijene, pakiranja, okusa, mirisa, boje, asocijacija i oglašavanja (Roman, Maas, 1995). Točnije, sve ono što služi identificiranju brenda uopće i njegovo diferenciranje od drugih brendova.

Kako bi brend stvorio „psihološku” prednost nad konkurentskim proizvodom, Keller ističe da bi on trebao zadovoljiti sljedeće kriterije: „zapamtljivost, značenje, dopadljivost, prenosivost, prilagodljivost i zaštitljivost” (Keller, 2003, str. 176). Keller (2009, str. 139155) navodi i kako se izgradnja uspješnog brenda zasniva na dvama modelima: modelu pozicioniranja brenda (Brand Positioning Model) i modelu rezonancije ili inzistiranja na brendu (Brand Resonance Model). Prvi - model pozicioniranja brenda - temelji se na uspostavljanju konkurentske prednosti tako da se kupcima komuniciraju sve prednosti brenda u odnosu na druge brendove. Takvo kompetitivno pozicioniranje može se razviti u četiri koraka:

stvaranje referentnog okvira u kojem se identificiraju ključni konkurenti te priroda odnosa među njima na samom tržištu,

definiranje točaka diferencijacije ${ }^{1}$ kroz identificiranje asocijacija i svojstava koji se razlikuju od konkurencije,

1 Puni naziv na engleskom jeziku je Point of Difference ili skraćeno POD. 
- definiranje točaka pariteta ${ }^{2}$ kroz identificiranje asocijacija i svojstava koje su slične konkurenciji,

stvaranje srži brenda koja se sastoji od tri do pet riječi, a u sebi objedinjuje obećanje i svrhu samog brenda (Keller, 2009, str. 139-155).

Model rezonancije ili inzistiranja na brendu temelji se pak na stvaranju intenzivnih i lojalnih odnosa s kupcima. Ključni čimbenici ovog modela su sljedeći:

identitet brenda kojim se predstavlja sâm brend i gradi se svijest o njemu, značenje brenda koje opisuje ulogu i svrhu brenda, a gradi se kroz definiranje točaka diferencijacije i pariteta,

odgovor brenda na želje potrošača koji se očituje kroz brojne aktivnosti brenda kojima se ulazi u njihove želje i potrebe,

gradnja osobnijih odnosa s kupcima kroz brojne aktivnosti koje za cilj imaju potaknuti odanost kupca (Keller, 2009, str. 139-155).

Samo pozicioniranje brenda podrazumijeva predefinirane elemente koji postaju nositelji cjelokupne strategije brenda. To su srž brenda, osobnost i imidž brenda, obećanje brenda te brend arhitektura (Insights Magazine, 2017).

Prema Kerru (2012, str. 6-7) pozicioniranje brenda temelji se na srži, točnije rečenici jedinstvenoj isključivo za sâm brend koja u sebi utjelovljuje cjelokupnu filozofiju brenda, kao i set asocijacija koje zauzimaju posebnu poziciju u svijesti potrošača. Srž brenda podrazumijeva ono što brend jest u svojoj biti: „njegov najstabilniji dio i ono što se prenosi kroz vrijeme i prostor i što tijekom vremena ne doživljava veće promjene” (Vranešević, 2007, str. 80).

Osobnost brenda je niz definiranih funkcionalnih i emotivnih obilježja koja se koriste kako bi se opisao pojedini brend te su direktan odraz njegove filozofije i misije. „Iz osobnosti brenda proizlazi imidž brenda, koji je uz njegovu poznatost, doživljenu kvalitetu, sjećanja i uspomene te pripadnost, 'familijarnost' i sviđanje dominantni činitelj tržišne vrijednosti brenda” (Kapferer, 2001, str. 37).

2 Puni naziv na engleskom jeziku je Point of Parity ili skraćeno POP. 
Važno je razlikovati pojmove brenda i imidža brenda. Dok brend čini ukupna pojavnost elemenata poput imena, znaka, vizualnog identiteta i drugih oblika dizajna i komunikacije, imidž brenda predstavlja percepciju koju potrošač formira prema znanju i informacijama koje dobiva od brenda (Wijaya, 2013, str. 58). Na istom tragu, Mowen i Minor (prema Wijaya, 2013, str. 58) definiraju imidž brenda kao skup asocijacija koje se urezuju u pamćenju potrošača. Isti autor ističe kako brend imidž predstavlja definirani okvir kojim se pokušava stvoriti trajna memorija o brendu, a koja pak proizlazi kao rezultat interpretacije poruka, svojstava, funkcionalnih prednosti, atmosfere stvorene u komunikaciji, karaktera ostalih korisnika te čak osobnosti vlasnika brenda. Jednostavno rečeno, brend imidž je sve ono što potrošač misli i osjeća kada je izložen nekom elementu brenda (Wijaya, 2013, str. 58).

Naposljetku, da bi se brendovima upravljalo na odgovarajući način, Clifton i Simmons (prema Vranešević, 2007, str. 107) upozoravaju kako treba sagledati važnost imaginativnog značenja identiteta brenda te komuniciranja brenda, vrijednost i pokretače vrijednosti brenda, brend kao sveukupno iskustvo od strane klijenata i brend kao središnje načelo djelovanja organizacije te ulogu društvene odgovornosti brenda.

Zaključno se može kazati kako se upravo posjedovanje snažnog brenda, jasno prepoznatljivog potrošačima, smatra jednim od najvažnijih čimbenika tržišne vrijednosti tvrtke (Vranešević, 2007), dok su s druge strane teorije i tehnike koje su se donedavno primjenjivale uglavnom u poslovnim okruženjima, sve više postale poželjni strateški alati za pokretanje promjena u brojnim drugim područjima (Skoko, 2012).

U kontekstu upravljanja s više brendova unutar portfelja tvrtki ili proizvoda, vrlo je važno definirati pojmove brend arhitekture, odnosno krovnog brenda te podbrendova i ekstenzija brenda. Brend arhitektura podrazumijeva strateško upravljanje brendovima unutar portfelja, njihovim međusobnim odnosima te asocijacijama koje svaki od njih unosi u narativ, samim time i percepciju krovnog brenda (Strebinger, 2004, str. 656). Pravilno definiranje brend arhitekture višestruko je korisno za svaku organizaciju jer se njome izbjegava unutarnja konkurencija pojedinih brendova te se postiže efekt sinergije koja rezultira povećanom vrijednosti za svaki od brendova u portfelju (Datzira-Masip, Poluzzi, 2014, str. 49).

U literaturi se navode dva općeprihvaćena modela brend arhitekture: House of Brands i Branded House. Model House of Brands predstavlja strukturu organizacije koja podrazumijeva više samostalnih brendova koji imaju vlastiti vizualni i verbalni identitet 
s vlastitim setom asocijacija, a koji su objedinjeni pod jedan krovni brend s kojim mogu imati slabiju ili snažniju poveznicu (Willow Marketing, 2018). U tom slučaju, svi brendovi koji se nalaze pod krovnim brendom bi po definiciji bili ekstenzije brenda.

Model Branded House (Aaker, Joachimsthaler, 2000, str. 15-17) pak označava organizacijsku strukturu u kojoj svi proizvodi, odnosno podbrendovi, nose vizualni i verbalni identitet (ime, slogan, logo) jednog krovnog brenda. Ovaj model se smatra ekonomičnijim i puno lakšim za upravljanje portfelja jer sve asocijacije proizlaze iz jednog imidža brenda i sve investicije se ugrađuju $u$ isti brend. Upravo je takav, potonji koncept najprihvatljiviji $u$ kontekstu Katoličke crkve i odnosa s njenim podbrendovima, kao što su sakralna i kulturna baština, crkvene karitativne institucije, svetišta te blaženici i sveci, koji su funkcionalno, asocijativno i emotivno nužno vezani uz krovni brend Crkve. Primjenom navedenog koncepta Katolička crkva bi osnažila svoj imidž i doprinijela transparentnijoj i cjelovitijoj komunikaciji prema odabranim ciljanim skupinama, ali i cjelokupnoj javnosti.

\section{Koncept brendinga u kontelkstu kršćanskih religija.}

Odnos marketinga, brenda, religije i vlastitog identiteta tek je posljednjih desetljeća postao predmet znanstvene i stručne obrade. I premda primjena marketinških koncepata u religiji seže u vrijeme reformacije u 16. i 17. stoljeću kada je kršćanska vjera predstavljena kao proizvod koji se može tržiti, prvi ozbiljni koraci, posebice u protestantskim zajednicama, poduzeti su osamdesetih godina prošlog stoljeća (Balog, 2012). O tom, za neke simbiotskom odnosu marketinga i religije, pisali su Schar, Erdem, Cutright i Fiztsimons te Einstein, dok su Usunier i Stolz (2014) primijetili kako je „religija postala proizvod, dok su proizvodi, odnosno brendovi, sâmi postali jedinstvene religije” (prema Baster, Beresford, Jones, 2018, str. 2). Jedna od glavnih pretpostavki brendinga je uvjerenje da ćemo korištenjem određenog proizvoda koji nosi znak, ime i dizajn određenog brenda postati bolji, brži i jači. Slična usporedba, iako pomalo trivijalna, može se propitkivati i u kontekstu religije koja nas uči da ćemo vjerovanjem i primjenom određenih religijskih postulata postati bolji i zadovoljniji ljudi.

Činjenica je da se u posljednje vrijeme sve više marketinških teorija i praksi implementira $\mathrm{u}$ svakodnevno djelovanje različitih Crkava i zajednica na institucionalnoj razini, ponajprije kada je riječ o kršćanskim protestantskim denominacijama. Potvrđuje to i navod Adebaya (prema Appah, 2017, str. 104) koji u svom radu ukazuje da su „Crkve, 
prije svega Evangelička i Pentekostalna, razvile jasnu namjeru da postanu «mega Crkve» i globalni brendovi”. Kako bi taj cilj i ostvarili pristupili su izradi marketinških strategija utemeljenih u pojmu „društvenog marketinga”, koji se uvelike oslanja na komunikaciju putem društvenih mreža. Takav marketing koristi se za razvijanje aktivnosti usmjerenih na promjenu ili održavanje istih obrazaca ponašanja ljudi u korist pojedinaca i društva $u$ cjelini (NSMC, 2019), dok ga Fjeldsoe, Marshall i Miller (2009) definiraju kao „intervenciju posebnu dizajniranu s ciljem utjecaja na ponašanje potrošača s ciljem poboljšanja osobne, društvene i ekonomske dobrobiti ljudi” (prema Appah, 2017, str. 104).

Različite religije i sustavi vjerovanja oduvijek su bile bitne čovjekove odrednice. Tako Niklas Luhmann vjeruje da je religija sama za sebe funkcionalan sustav i kao takva nije potrebna antropološki, to jest individualno, već je potrebna za društvo kao komunikacijski sustav. $U$ ranijoj povijesti ona je shvaćana kao temeljna i u društvu ukorijenjena višefunkcionalna ustanova čiji se autoritet teško može narušiti (Markešić, 2001).

Istraživanje koje je 2017. godine objavio istraživački centar Pew pokazalo je kako se $84 \%$ ljudi u cjelokupnoj populaciji izjašnjava religioznima. Pritom se najveći postotak, njih 31,2\%, svrstalo među pripadnike kršćanskih religija (Pew Research Center, 2017). Kada je riječ o stanovnicima Hrvatske, prema istraživanju European Values Study, njih 84\% smatra se religioznima (Baloban, Črpić, Ježovita, 2019). Stoga i ne čudi činjenica da na institucionalnoj razini Katoličke crkve i različitih kršćanskih denominacija postoji velika potreba za razumijevanjem obrazaca ponašanja vjernika, kako bi se na odgovarajući način osmislile ključne poruke koje se žele komunicirati.

I premda neki autori smatraju da tzv. potrošači religije koriste iste kriterije za odabir religije i bilo kojeg drugog proizvoda na tržištu (Appah, 2017, str. 105) te da bi se marketinški pristup Crkava trebao zasnivati na istraživanju želja i navika potrošača, a rezultate i dobivene uvide u svijest potrošača upotrijebiti za razvoj „religijskih proizvoda”, neki kritičari poput Kennesona otvoreno kritiziraju bilo kakvu mogućnost korištenja takvih koncepata. Razlog tomu je, kako navodi, „nemogućnost kvantificiranja kvalitativnih obilježja (primjerice: vjere, duhovnosti, predanosti poslanju), ali i zbog pretpostavke da su marketinški alati vrijednosno neutralni, dok vjerski kontekst to svakako nije” (Kenneson, 1993 prema Balog, 2012, str. 44). Međutim, ako brending pokušamo shvatiti kao postavljanje referentnog i sveobuhvatnog okvira za rješavanje komunikacijskih izazova te kao alat za lakše upravljanje vlastitim podbrendovima, onda možemo govoriti o vrlo korisnom mehanizmu koji olakšava i učvršćuje svakodnevno funkcioniranje religijskih zajednica na institucionalnoj razini. 


\subsection{Srž i osobnost brenda Katoličke crkve}

Kada govorimo o brendu Katoličke crkve, kao i kod ostalih religijskih zajednica javljaju se poteškoće prilikom primjene marketinških i brending koncepata. Jedna od njih je svakako površna primjena zakona diferencijacije i kompetitivnog pozicioniranja komercijalnih brendova u kojem je jedan proizvod bolji od drugog. U kontekstu religije takav model posljedično može uzrokovati određene antagonizme kod pripadnika drugih religijskih uvjerenja. Papa emeritus Benedikt XVI rješenje izazova vidi u afirmaciji vlastitih religijskih uvjerenja i tvrdnji, pokazujući pritom toleranciju i poštovanje prema vjerskim uvjerenjima i tvrdnjama pripadnika drugih Crkava (Ratzinger, 2004). Katolička crkva naučava i vjeruje da za razliku od drugih društvenih tvorevina i organizacija ima svoje dvije naravi: ljudsku i božansku. Dakle, Crkva smatra da je ona i „društvena organizacija sa svim pripadajućim obilježjima, ali istovremeno, i duhovna zajednica vjernika” (Balog, 2012, str. 46). Kada govori o božanskoj naravi misli se, prije svega, na Crkvu kao zajednicu vjere, nade i ljubavi sazdanu od Isusa Krista (Lumen gentium, 8, prema Kušar, 2008) pa joj se posljedično tomu pripisuju i dodatni atributi transcendentnosti i mističnosti. To je, kako navodi Balog, ključni faktor po kojem se Katolička crkva razlikuje od drugih društvenih organizacija i marketinški poslovnih koncepata koji su utemeljeni na ovostranosti i imanentnosti (Balog, 2012).

Također, kao što je objašnjeno u drugom poglavlju ovoga rada, brending je u svojoj biti marketinški alat namijenjen stvaranju profita na komercijalnim tržištima, što nije u korelaciji s poslanjem i misijom Katoličke crkve. Prema temeljnim dokumentima učiteljstva Katoličke crkve, vjera je Božji dar (Katekizam Katoličke crkve, 2016, str. 57), krepost koju ne možemo zadobiti bez Božje milosti (Dei verbum, 5, prema Kušar, 2008). To je ujedno i ključ za razumijevanje srži brenda Katoličke crkve koja se ne može poistovjetiti s idejom ranije spomenutih protestantskih denominacija da postane „mega Crkva” ili globalni brend koji bi vjeru definirao kao religijski proizvod dostupan na tržištu.

Ako polazimo od definicije srži brenda, koja ga kako je već spomenuto određuje kao njegov najstabilniji dio i ono što se prenosi kroz vrijeme i prostor i što tijekom vremena ne doživljava veće promjene, može se zaključiti da se bit brenda Katoličke crkve odražava u samom poslanju i misiji Crkve u svijetu: da svjedoči vjeru i nadu utemeljenu na poruci evanđelja. Iz njezina poslanja da „postaje pristuna svim ljudima i narodima, da ih primjerom života i propovijedanjem, sakramentima i ostalim sredstvima milosti privede k vjeri” (Ad gentes, 5, prema Kušar, 2008, str. 516), proizlazi i njezina misionarska narav da Isusovi učenici idu po svem svijetu i naviještaju evanđelje (usp. Ad gentes, 6, prema Kušar, 2008). 
Kako je i protumačeno $u$ teorijskom prikazu ključnih pojmova $u$ brendingu, osobnost brenda je niz definiranih funkcionalnih i emotivnih obilježja koja se koriste kako bi se opisao pojedini brend te su direktan odraz njegove filozofije i misije. Kada govorimo $u$ kontekstu Katoličke crkve, oni koji najvidljivije utjelovljuju srž, osobnost, filozofiju i misiju njezina brenda su njeni poglavari - pape. Oni su prije svega vjerski autoritet, „pravi i autentični učitelji vjere, svećenici i pastiri” (Christus Dominus, 3 prema Ikić, 2013, str. 274), ali također i politički i moralni autoritet te najistaknutiji predstavnici Katoličke crkve, pozvani kako ističe papa Franjo „služiti i voditi osobnim primjerom” (Vatican.va, 2017).

Poziv pape Franje upućen je, između ostalog, i drugim poglavarima i članovima Crkve - biskupima, svećenicima, redovnicima i redovnicama, ali i vjernicima laicima koji nisu crkveni službenici. Svi su oni u svom djelovanju pozvani biti komunikatori vrijednosti brenda Katoličke crkve, prije svega autentičnosti kršćanskog življenja, poniznosti i empatije. Tako tajnik Papinskog vijeća za sredstva društvenog priopćavanja, biskup Paul Tighe, primjećuje da snaga brenda Katoličke crkve ne proizlazi iz jednog centraliziranog izvora, već se ona očituje na lokalnoj, mikro razini. Pojašnjavajući tu tvrdnju biskup Tighe koristi primjer američkih prehrambenih kompanija Starbucks i McDonald`s te naglašava kako su njihovi objekti, proizvodi i usluge unificirani i jednaki u svim dijelovima svijeta, dok Katolička crkva njeguje različitost, posebice kada je u pitanju bogatstvo liturgije, glazbe, jezika, svetišta i prošteništa, kulta svetaca i blaženika i sl. (Catholic News Service, 2017). Tako se može zaključiti da svaka mjesna Crkva, zahvaljujući svojoj različitosti, ima svoje podbrendove, koji u konačnici tvore cjeloviti imidž brenda Katoličke crkve.

Ako je pak riječ o našem lokalnom hrvatskom okviru onda valja istaknuti brojne podbrendove koji su kroz 14-stoljetnu povijest doprinosili imidžu brenda Katoličke crkve, ali i imidžu nacionalnog brenda Hrvatske. Mnogi su velikani duha svojim radom i životom zadužili Hrvatsku te tako ostali upamćeni u kolektivnoj memoriji hrvatskog naroda.

Više istraživanja javnog mnijenja (Hrvatski obzor, 1999; Millenium promocija, 2011; Millenium promocija i Večernji list, 2013 prema Skoko, 2014) pokazala su kako stanovnici Hrvatske među velikane naroda koji su utkani u izgradnju nacionalnog brenda Hrvatske redovito svrstavaju crkvene ličnosti. Prije svega isusovca Ruđera Boškovića, biskupa Josipa Jurja Strossmayera, svećenika Fausta Vrančića, sv. Nikolu Tavelića, sv. Leopolda Bogdana Mandića te kardinala Alojzija Stepinca, čiji će doprinos u oblikovanju imidža brenda Katoličke crkve i nacionalnog brenda Hrvatske biti detaljnije razrađen u istraživačkom dijelu rada. 


\section{Predmet, problem i cillj istraživanja}

U središtu istraživačkog interesa ovog rada je predodžba studentske populacije o zagrebačkom nadbiskupu i kardinalu Alojziju Stepincu. Zato se čini uputnim izdvojiti tek nekoliko faktografskih podataka o toj crkvenoj ličnosti. Alojzije Stepinac rođen je u Brezariću pokraj Krašića 1898. godine. Sa svojih trideset i šest godina imenovan je zagrebačkim nadbiskupom koadjutorom, a nakon smrti tadašnjeg nadbiskupa Antuna Bauera preuzima vodstvo teritorijalno i brojčano najveće biskupije u Hrvatskoj (Benigar, 1993).

Djelovao je u vrtlogu triju tipova političkog totalitarizma: fašizma, nacionalsocijalizma i komunizma (Batelja, 2000), a 1946. godine na montiranom komunističkom sudu osuđen je na zatvorsku kaznu od šesnaest godina te daljnjih pet godina lišenja svih građanskih prava (Harris, 2016). Stepinac je kaznu izdržavao u Lepoglavi od 1946. do 1951. te od 1951. do svoje smrti 1960. godine u župnoj kući rodne župe u Krašiću, a blaženim ga je 1998. godine proglasio papa Ivan Pavao II. pred više od 500 tisuća vjernika u Mariji Bistrici (Batelja, 2017).

Istraživanja javnog mnijenja poput onog hrvatske agencije za odnose s javnošću Millenium promocija iz 2013., predvođeno Božom Skokom, te medijski izbori najvećih hrvatskih velikana poput onog iz Večernjeg lista iz 2011. godine pokazuju kako u narodu upečatljivo živi uspomena na „hrvatskog blaženika i mučenika Alojzija Stepinca” (Skoko, 2014, str. 87). I ne samo to, već i potvrđuju činjenicu da teme vezane uz djelovanje nadbiskupa Stepinca za vrijeme bivših režimskih sustava u Hrvatskoj tijekom prve i druge polovice 20. stoljeća pobuđuju velik interes $u$ javnom prostoru. No, prečesto se događa da se toj problematici pristupa s ideoloških pozicija, bez poznavanja konteksta vremena i s nedostatkom znanstveno utemeljenog kritičkog odmaka. ${ }^{3}$

Ovaj rad ima tri cilja.Prije svega, žele se ispitati predodžbe studentske populacije okardinalu Stepincu te analizirati kakav imidž među ispitanicima uživa taj crkveni velikodostojnik. Razlog zašto glavni uzorak ovog istraživanja čini mlada, studentska populacija je, između ostalog, i nedavno provedena i objavljena studija o mladima u Hrvatskoj Zaklade Friedrich-Ebert, koja je pokazala kako $49 \%$ mladih od 14 do 29 godina ${ }^{4}$ smatra da bavljenje

3 U prilog navedenoj tvrdnji: https://www.index.hr/vijesti/clanak/burna-rasprava-u-otvorenom-oko-stepinca-posvadjali-se-hrvoje-klasic-i-visnja-staresina/982637.aspx, pristup: 8. kolovoza 2019.; https://net.hr/danas/hrvatska/sastanak-komisije-u-vatikanu-katolicki-i-pravoslavni-strucnjaci-oko-stepinca-se-ne-slazu/, pristup: 8. kolovoza 2019.; https://www.24sata.hr/news/ stepinac-je-blazen-ali-postoje-neke-nejasne-povijesne-tocke-628317, pristup: 8. kolovoza 2019.

$4 \mathrm{U}$ tu skupinu spada i populacija obuhvaćena ovim istraživanjem. 
nedavnom prošlosti treba prepustiti isključivo povjesničarima (FES, 2019, str. 38). Stoga je za pretpostaviti da je riječ o uzorku neopterećenom ideološkim narativima, što je jedan od ključnih preduvjeta za objektivno pristupanje ovoj kompleksnoj temi.

Cilj je rada, također, odgovoriti na istraživačko pitanje doprinosi li kardinal Stepinac pozitivnoj ili negativnoj percepciji nacionalnog brenda Hrvatske te ukazati na potrebu komunikacijskog upravljanja brendovima Katoličke crkve. Kada je riječ o hrvatskim prilikama, primjetan je nedostatak svijesti o strateškom planiranju komunikacije. Unatoč tomu što je „okvir institucionalne komunikacije jasno definiran u postkoncilskim ${ }^{5}$ dokumentima crkvenog Učiteljstva te tomu što su pojedine biskupijske zajednice i crkvene institucije na dobrom putu integriranja smjernica, većina ne komunicira strateški i proaktivno" (Trbušić, 2018, str. 70).

Na tom je tragu i istraživanje Suzane Peran o medijskoj komunikaciji Crkve u Hrvatskoj, koje je pokazalo kako se mnogi naputci ne samo općih crkvenih dokumenata o medijima nego i pastoralnih smjernica hrvatskih biskupa „Crkva i mediji” ${ }^{\circ}$ nisu ostvarili. Posebno se to odnosi na „zahtjev utemeljenja ureda za medije na (nad)biskupijskoj razini, postojanje pastoralnog plana za područje medijskog djelovanja te nazočnost Crkve na internetu" (Peran, 2018, str. 866).

\subsection{Hipoteze istraživanja}

Hipoteze koje će se istraživanjem propitivati su sljedeće:

$H_{1}$ : Lik kardinala Stepinca doprinosi pozitivnoj percepciji nacionalnog brenda Hrvatske. $\mathrm{H}_{2}$ : Studenti se o kardinalu Stepincu u većini slučajeva informiraju putem novih medija. $H_{3}$ : Studenti smatraju da Katolička crkva ne ulaže dovoljno napora u komuniciranju svojih podbrendova.

\subsection{Metodologija rada}

Kako bi se ustanovila točnost tvrdnji postavljenih u hipotezama, konstruiran je anonimni anketni upitnik koji se sastojao od pet zatvorenih i šest otvorenih pitanja. Proces konstrukcije upitnika temelji se na proučavanju stručne literature iz područja marketinga i brendinga te definiranju područja mjerenja. Upitnik sastavljen od jedanaest čestica primijenjen je na namjernom i svrsishodnom uzorku od 143 ispitanika studenata 
preddiplomskih i diplomskih studija komunikologije na Fakultetu hrvatskih studija Sveučilišta u Zagrebu te Hrvatskog katoličkog sveučilišta, kao i studenata na Edward Bernays Visokoj školi za komunikacijski menadžment. Upitnik je distribuiran u papirnatoj verziji i to tijekom travnja, svibnja i lipnja 2019. godine. Teme pitanja ove specifične skupine odnosile su se na osnovno poznavanje lika kardinala Alojzija Stepinca, asocijacije koje uz njega vežu, kanale putem kojih se o njemu informiraju, percepciju njegova lika u kontekstu očuvanja ili narušavanja imidža Hrvatske i sl. Valja istaknuti kako je zbog veličine uzorka ovdje riječ o preliminarnom istraživanju, točnije samo dijelu većeg istraživačkog projekta koje se planira provesti u budućnosti.

\section{Istraživanje i interpretacija rezulltata}

Sukladno ciljevima istraživanja i postavljenim hipotezama, pristupilo se analizi stavova ispitanika o kardinalu Alojziju Stepincu kao elementu u oblikovanju imidža nacionalnog brenda Hrvatske.

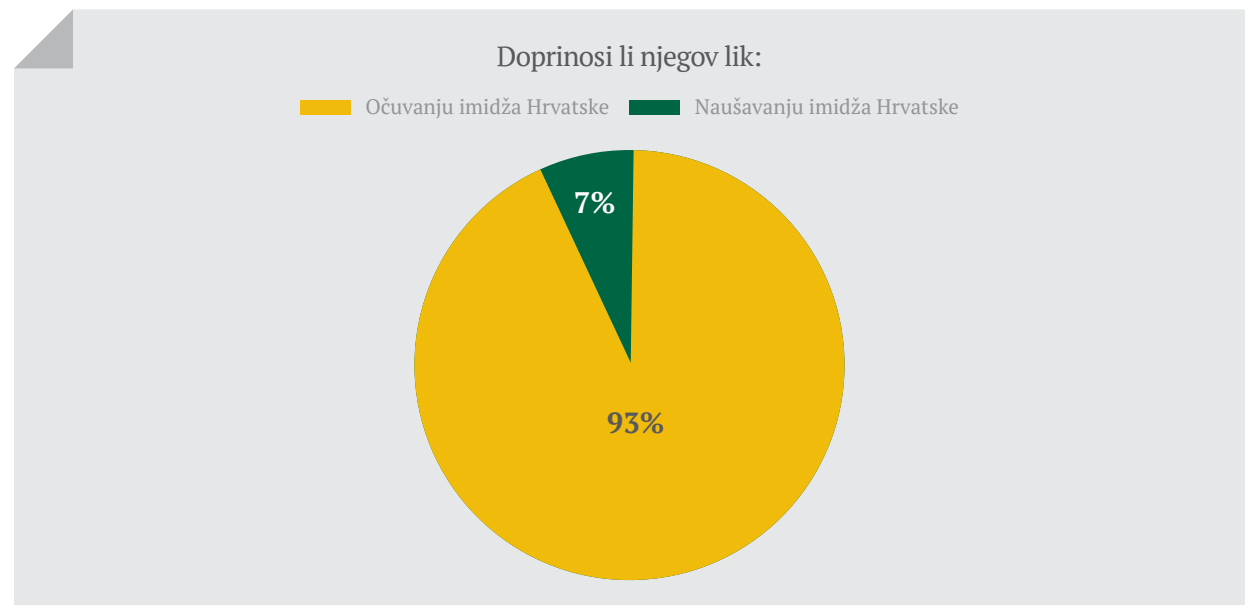

Grafikon 1. Percepcija ispitanika o kardinalu Stepincu kao pozitivnom ili negativnom elementu u oblikovanju imidža nacionalnog brenda Hrvatske $(\mathrm{N}=143)$

Prema rezultatima iz Grafikona 1 vidljivo je da većina ispitanika (93\%) smatra kako lik kardinala Alojzija Stepinca doprinosi očuvanju imidža nacionalnog brenda Hrvatske. Uz to, većina ispitanika kardinala Stepinca ocjenjuje pozitivnom povijesnom ličnošću. 
Na pitanje zašto kardinala Stepinca vide kao osobu koja doprinosi očuvanju imidža nacionalnog brenda Hrvatske, većina ispitanika afirmativno odgovara kako je on bio: „uzor vjernosti”, „svijetla točka hrvatskog naroda u mračnom trenutku hrvatske povijesti”, „primjer malog čovjeka koji je učinio mnogo” te da je „pomagao potrebitima”, „prosvjedovao protiv progona Židova, Srba i rasnih zakona”, da je „spašavanjem Židova i drugih pokazao kako se Crkva odnosila prema narodu u teškim trenucima” i sl.

Također, valja istaknuti kako 97,2\% ispitanika zna tko je Alojzije Stepinac te su upoznati s općenitim informacijama iz njegova života, što je dodatna potvrda vjerodostojnosti gore navedenih rezultata. Među općenitim informacijama ispitanici su najčešće izdvajali povijesne datosti poput onih da je Alojzije Stepinac bio zagrebački nadbiskup i kardinal, da je rođen na području Krašića, da je bio u zatvoru i da je proglašen blaženim.

Osim toga, $u$ ovom dijelu interpretacije rezultata istraživanja bitno je ukazati i na asocijativnu dinamiku koja se veže uz lik kardinala Stepinca. Pokazalo se kako ispitanici $\mathrm{u}$ velikoj većini slučajeva lik kardinala Stepinca povezuju s afirmativnim asocijacijama, poput domoljublja, hrabrosti, istine, snage, vjere, neustrašivosti, nepokolebljivosti ili mučeništva.

Na temelju dobivenih rezultata potvrđena je prva hipoteza (H1): Lik kardinala Stepinca doprinosi pozitivnoj percepciji nacionalnog brenda Hrvatske.

\section{Kanali putem kojih se mladi informiraju o kardinalu Stepincu}

Osobni kontakti

Internet i društvene mreže

Tradicionalni mediji

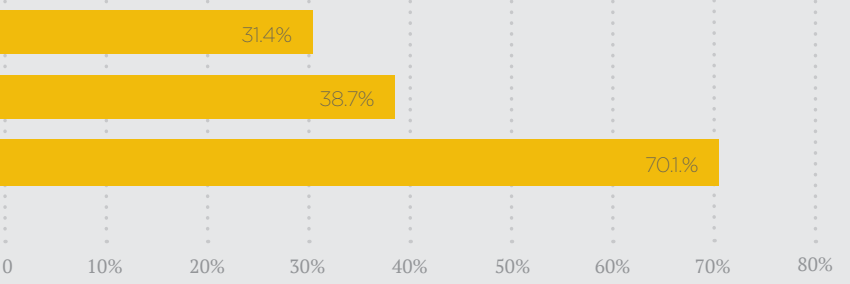

Grafikon 2. Izvori informacija i percepcija kardinala Stepinca u hrvatskom medijskom prostoru (N=143)

Kada je riječ o izvorima informacija, odnosno kanalima putem kojih se ispitanici informiraju o kardinalu Stepincu, sudionici istraživanja mogli su odabrati više ponuđenih odgovora. Tako je većina njih $(70,1 \%)$ odgovorila kako se o kardinalu Stepincu najčešće informiraju putem tradicionalnih medija: tiska, radija i televizije. Slijedi informiranje putem interneta i društvenih mreža $(38,7 \%)$ te putem osobnog kontakta $(31,4 \%)$. 
Ako bi se ovi rezultati usporedili s recentnim istraživanjima o korištenju interneta među mladima u Hrvatskoj u dobi od 14 do 29 godina, što odgovara i dobi populacije koja je obuhvaćena našim istraživanjem, mogu se uočiti pojedinosti vidljive iz istraživanja Zaklade Friedrich-Ebert. Naime, prema toj studiji 98\% mladih u Hrvatskoj ima osiguran svakodnevni pristup internetu, a njegovo se prosječno dnevno korištenje povećalo na 3.49 sati, dok se prosječno dnevno gledanje televizije smanjilo na 2.26 sati. No, za razumijevanje šire slike valja promotriti svrhu korištenja interneta među mladom populacijom. Naime, 83\% mladih često pristupa internetu u svrhu korištenja društvenih mreža, dok tek nešto više od polovice ispitanih (51\%) internetu pristupa u svrhu čitanja vijesti i informiranja. $\mathrm{K}$ tome, $\mathrm{u}$ istoj je studiji indikativna činjenica kako je televizija kao tradicionalni medij ostala primarni izvor informiranja o političkim događajima među mladima (FES, 2019, str. 44-62), što je, može se zaključiti, samo potvrda rezultata u Grafikonu 2, jer nije rijetkost da se vjerska tematika $u$ hrvatskim tradicionalnim medijima prikazuje $u$ društvenom $i$ političkom kontekstu. Naime, prema istraživanju provedenom u sklopu projekta „Vjerska tematika u hrvatskom medijskom prostoru”, koje je na temelju analize 710 priloga objavljenih u različitim medijima, vjerska tematika je u $34,1 \%$ (u više od jedne trećine) slučajeva prikazana unutar društvenog konteksta (Valković, 2019, str. 98-99).

Osim toga, varijabla koja se u ovom dijelu istraživanja također promatrala je i percepcija kardinala Stepinca $\mathrm{u}$ hrvatskom medijskom prostoru. Naime, većina ispitanika, njih 61,9\%, smatra kako hrvatski novinari o temi kardinala Stepinca izvještavaju neutralno, dok je njih tek $11,2 \%$ izvještavanje o toj temi ocijenilo negativnim. Konačno, može se ustvrditi da je druga hipoteza (H2): Studenti se o kardinalu Stepincu u većini slučajeva informiraju putem novih medija opovrgnuta.

Ovo je istraživanje pokazalo i da mladi ispitanici prepoznaju i druge crkvene ličnosti iz hrvatske povijesti kao one koje pozitivno utječu na imidž Hrvatske. Ako bi se rangirala pojavnost ličnosti od najučestalijeg do najmanje učestalog, redoslijed bi izgledao ovako: Josip Juraj Strossmayer, zatim Ivan Merz pa Franjo Kuharić, Ruđer Bošković te Leopold Bogdan Mandić. Ipak, kada je riječ o naporima koje Katolička crkva u Hrvatskoj ulaže pri komuniciranju svojih podbrendova, koji osim gore navedenih svetaca i blaženika uključuju i promidžbu svoje kulturne i sakralne baštine ili predstavljanje svojih karitativnih aktivnosti, ispitanici su ocijenili kako se oni ne poduzimaju u dovoljnoj mjeri (Grafikon 3). Dakle, može se zaključiti kako je treća hipoteza $\left(\mathrm{H}_{3}\right)$ : Studenti smatraju da Katolička crkva ne ulaže dovoljno napora pri komuniciranju svojih podbrendova potvrđena. 
Ulaže li crkva u Hrvatskoj dovoljno napora u komuniciranju svojih podbrendova?

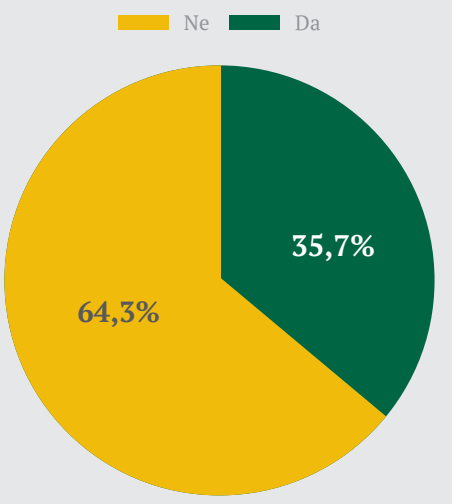

Grafikon 3. Percepcija stavova ispitanika o aktivnostima Katoličke crkve u komuniciranju svojih podbrendova (N=143)

\section{Zalključalk}

Ovaj je rad u svom teorijskom dijelu pokazao kako univerzalni koncept brendinga nije nužno primjenjiv na svaku društvenu organizaciju. Posebice kada je riječ o religijskim zajednicama poput Katoličke crkve, čije se djelovanje ne može svrstati isključivo u kategorije tržišnog natjecanja. Ipak, ako se suvremeni koncepti brendinga pokušaju shvatiti kao postavljanje referentnog i sveobuhvatnog okvira za rješavanje komunikacijskih izazova te kao alat za lakše upravljanje svojim podbrendovima, onda možemo govoriti o vrlo korisnom mehanizmu koji olakšava svakodnevno funkcioniranje Katoličke crkve na institucionalnoj razini. Pritom je važno ostati vjeran srži brenda Katoličke crkve, kao i biti svjestan činjenice da svaka mjesna Crkva zahvaljujući svojoj različitosti ima svoje podbrendove, koji u konačnici tvore cjeloviti imidž nacionalnog brenda i brenda Katoličke crkve.

Na tom je tragu istraživački dio ovog rada, koji je prvi put ispitao predodžbe studenata komunikologije na Fakultetu hrvatskih studija Sveučilišta u Zagrebu, Hrvatskog katoličkog sveučilišta te Edward Bernays Visoke škole za komunikacijski menadžment o kardinalu Alojziju Stepincu kao elementu u oblikovanju imidža nacionalnog brenda Hrvatske. Iz rezultata je vidljivo kako, unatoč prijeporima koji se u određenom dijelu javnosti vežu 
za njega, navedena studentska populacija kardinala Stepinca nesumnjivo percipira kao pozitivnu povijesnu ličnost koja doprinosi očuvanju imidža nacionalnog brenda Hrvatske.

Uz to, istraživanje je pokazalo kako se navedena studentska populacija o liku kardinala Stepinca najviše informira putem tradicionalnih medija te da općenito nisu zadovoljni naporima Crkve u Hrvatskoj da komunicira svoje podbrendove, što svakako može poslužiti kao poticaj crkvenim institucijama. Prije svega, da na institucionalnoj razini razmisle o komunikacijskim kanalima kojima žele posredovati ključne poruke, ali i da razmotre donošenje jedinstvenih komunikacijskih strategija kako bi svojim dionicima približili srž, osobnost, filozofiju i misiju brenda Katoličke crkve i njezinih podbrendova.

\section{Popis literature}

- Aaker, D., Joachimsthaler, E. (2000). The Brand Relationship Spectrum: The Key to the Brand Architecture Challenge, California Management Review, 42 (4), 8-23.

- Appah, G. O., George, B. P. (2017). Understanding Church Growth through Church Marketing: An Analysis on the Roman Catholic Church's Marketing Efforts in Ghana, Journal of Economics and Business Research, 23 (1), 103-122.

- Baloban, J., Črpić, G., Ježovita, J. (2019). Vrednote u Hrvatskoj od 1999. do 2018. prema European Values Study. Zagreb: Katolički bogoslovni fakultet Sveučilišta u Zagrebu, Hrvatsko katoličko sveučilište, Kršćanska sadašnjost.

- Balog, A. (2012). Marketing u Crkvi. Suvremeni koncept nove evangelizacije naroda. Osijek, Daruvar: Visoko evanđeosko teološko učilište u Osijeku, Logos.

- Baster, D., Beresford S., Jones, B. (2019). The "brand” of the Catholic Church in England and Wales: Challenges and opportunities for communications, J Public Affairs, 19 (1), 1-12.

- Batelja, J. (2000). Propovijedi, govori, poruke (1934. - 1940.). Zagreb: Postulatura blaženog Alojzija Stepinca.

- Batelja, J. (2017). Komunistički progon i mučeništvo blaženoga Alojzija Stepinca. Zagreb: Postulatura blaženog Alojzija Stepinca.

- Benigar, A. (1993). Alojzije Stepinac, hrvatski kardinal. Zagreb: Glas Koncila, Hrvatska franjevačka provincija sv. Ćirila i Metoda.

- Datzira-Masip, J., Polluzi, A. (2014). Brand architecture management: The case of four tourist destinations in Catalonia. Journal of Destination Marketing \& Management, 3, 48-58.

- De Chernatony, L., McDonald, M. (2005). Creating Powerful Brands. Massachusetts: Butterworth-Heinemann.

- Dibb, S., Simkin, L., Pride, W. M., Ferrell, O. C. (1995). Marketing. Zagreb: Mate.

- Harris, R. (2016). Stepinac. His Life and Times. Leominster: Gracewing.

- Ikić, N. (2013). Odnos autoriteta primata i episkopata. Teološki pogled u svjetlu Drugoga vatikanskog koncila i doprinosa nekih teologa, Bogoslovska smotra, 83 (2), 263-286.

- Insights Magazine (2017). The four basic elements of brand strategy. Dostupno na: https://cdn2.hubspot.net/hubfs/455845/ Insights/03.17_March\%20Issue\%20v1.1.pdf?t=1490568813060. Pristupljeno 15. prosinca 2019.

- Kapferer, J. N. (2001). Strategic Brand Management. London: Kogan Page.

- Katekizam Katoličke crkve (2016). Dostupno na: http://hbk.hr/wp-content/uploads/2018/11/Katekizam_Katoli\%C4\%8Dke-Crkve. pdf. Pristupljeno 23. kolovoza 2019.

- Keller, L. K. (2003). Strategic Brand Management: Building, measuring, and managing brand equity. Upper Saddle River: Prentice Hall.

- Keller, L. K. (2009). Building strong brands in a modern marketing communications environment. Journal of Marketing Communications, 15 (2-3), 139-155.

- Kušar, S. (2008). Drugi vatikanski koncil. Dokumenti. Zagreb: Kršćanska sadašnjost. 
- Kerr, G., Balakrishnan, M. S. (2012). Challenges in managing placebrands: The case of Sydney. Place Branding and Public Diplomacy, 8 (1), 6-16.

- Kotler, P. (2000). Marketing management. New Jersey: Prentice Hall.

- Kotler, P., Gertner, D. (2004). Country as a brand, product and beyond: a place marketing and brand management perspective. U: Morgan, N., Pritchard, A., Pride, R. Destination branding. Creating the unique destination proposition. Oxford: Elsevier ButterworthHeinemann.

- Markešić, I. (2001). Luhmann o religiji. Zagreb: Hrvatsko filozofsko društvo.

- Olins, W. (2008). Brendovi. Marke u suvremenom svijetu. Zagreb: Golden marketing-Tehnička knjiga.

- Peran, S. (2018). Vjerski mediji u službi unutarcrkvenog dijaloga. Medijska komunikacija Crkve u Hrvatskoj na tragu smjernica HBK. Crkva i mediji. Bogoslovska smotra, 88 (3), 853-871.

- Pew Research Center (2017). The Changing Global Religious Landscape. Dostupno na: https://www.pewforum.org/2017/04/05/ the-changing-global-religious-landscape/. Pristupljeno 19. kolovoza 2019.

- Ratzinger, J. (2004). Truth and Tolerance: Christian Belief and World Religions. San Francisco: Ignatius Press.

- Roman, K., Mass J. (1995). Kako oglašavati. Radovljica: Zbirka Virgo Advertising.

- Skoko, B. (2014). Hrvatski velikani. Zagreb: Večernji list.

- Skoko, B. (2012). Važnost brendiranja države i uloga javne diplomacije u suvremenim međunarodnim odnosima - hrvatske mogućnosti i neiskorištene prilike. U: Markić, Boban, A. (ur.), Javna diplomacija: imidž nacije i brendiranja: zbornik radova (str. 9-34), Zagreb: Hans-Seidel-Stiftung.

- Strebinger, A. (2004). Strategic Brand Concept and Brand Architecture Strategy - A Proposed Model. Advances in Consumer Research, 31, 656-660.

- Trbušić, D. (2018). Uloga katoličkih medija u procesu informiranja o crkvenim zbivanjima. U: Peran, S. (ur.), Novinarstvo pred izazovom Radosne vijesti. Uloga i mjesto katoličkih medija u Crkvi i u društvu (str. 62-72). Zagreb: Hrvatsko društvo katoličkih novinara, Teovizija.

- Valković, J. (2019). (Vjerska) informacija - u procjepu između medijske logike i očekivanja vjernika. U: Valković, J. (ur.), Vjerska tematika u hrvatskom medijskom prostoru (str. 95-117). Zagreb: Hrvatsko katoličko sveučilište.

- Vatican.va (2017). Papin nagovor uz molitvu Anđeo Gospodnji (5. studenog 2017.). Dostupno na: http://w2.vatican.va/content/ francesco/hr/angelus/2017/documents/papa-francesco_angelus_20171105.html. Pristupljeno 22. kolovoza 2019.

- Wijaya, B. S. (2013). Dimensions of Brand Image: A Conceptual Review from the Perspective of Brand Communication. European Journal of Business and Management, 5 (31), 55-65. 


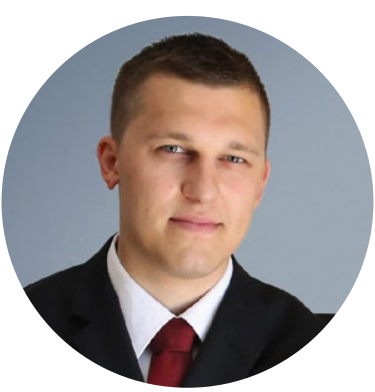

\section{Davor Trbušić}

He is a teaching assistant at the Department of Communication Sciences at the Faculty of Croatian Studies, University of Zagreb. After completing his studies in Communication Sciences at the Faculty of Croatian Studies, he enrolled in a postgraduate doctoral study at the University of Zagreb. From 2014 to 2019 he worked as a Communications Advisor at the Press Office of the Archdiocese of Zagreb, where he was responsible for planning, implementing and evaluating communication projects. His areas of scientific interest are public relations, crisis communication, church communication and journalistic ethics. He is an External Associate at Croatian Catholic University (Communication Department) and at Edward Bernays University College. 


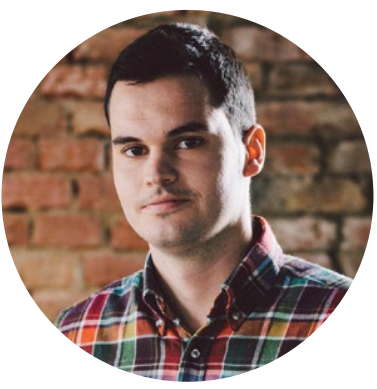

\section{Stipan Rimac}

Stipan Rimac earned a Master's degree in Communications sciences in 2013 at the Faculty of Croatian Studies and is now a doctorand at the Faculty of Humanities and Social Sciences of the University of Zagreb. He is a member of the rewarded team of brand consultants at the branding agency Fabular where he is in charge of analytical research of trends, competitive environment of the brands as well as the development of the brand and communication strategies. He has worked on the development of strategies for many brands such as Infobip, The city of Trogir, Maistra Hotels\&Resorts, Medora Hotels \&Resorts, Croatia Insurance Company, Algebra, Oryx Grupa, Q Software, Omnizon Networks, Bornfight, and 3AC Core Materials. As a part of the team, he has been awarded with the REBRAND 100 ${ }^{\circledR}$
Global, considered as the most prestigious award for rebranding in the world. At the same time, he is an External Associate at the Department of Communication sciences at the Faculty of Croatian Studies, where he teaches Marketing Communications and Publicity. 